\title{
Government Policy of Mining Business License (Iup) Production Operations for Social Justice Community around Realized
}

\author{
La Sensu ${ }^{1)}$, Achmad Ruslan ${ }^{2)}$, Abdul Razak ${ }^{3)}$, HM. DJafar Saidi ${ }^{4)}$ \\ 1) Doctorate Program of law Science, Faculty of Law Hasanuddin University, Makassar, South Sulawesi of \\ Indonesia. \\ ${ }^{234)}$ Professor, Faculty of Law Hasanuddin University, Makassar, South Sulawesi of Indonesia
}

\begin{abstract}
This study aims to explain the Government's policy on Mining Production Operation IUP mining on surrounding communities, and to identify and analyze how government policy on IUP production of mining on the environment as a life support communities, as well as to analyze the extent of mining entrepreneur attitude creates benefits for the surrounding community in efforts to achieve social justice. This study uses data collection methods with two approaches, namely: literature research and field research methodology. Implementation of Government Policy on the preparation of Production Operation IUP Mining in Southeast Sulawesi by using equipment Participatory Rural Appraisals (PRA) is modified according to the needs of the field. The results of the analysis of this study found that the Government Policy on Production Operation IUP Mining in Southeast Sulawesi, showed that the enactment of Law No. 4 of 2009 on Mineral and Coal are still far from achieving the community prosper because management of mining is still dominated by a few indicators which are enriching themselves Entrepreneur and the group itself, while granting permission to the entrepreneurs in the field of environmental management and AMDAL was still there irregularities acquisition, as well as business entrepreneurs in creating benefits for the surrounding community mining community has not been able to prosper.

Keywords: Government Policy, Production Operation IUP, Social Justice
\end{abstract}

\section{Introduction}

Policy or commonly called the Police [25], is closely associated with authority, and policy arise because of the authority and the authority associated with the position, a policy can only be made in respect of the authority inherent in a person. People who do not have the authority cannot issue a policy, and the policy provisions that have taken the authority due to circumstances or particular problems or changes. In the midst of our national life today, hopes and ideals of social justice was even more difficult to materialize. In fact, it can be said that these ideals are becoming even more forgotten. Many of the symptoms in the community, which reveal how the nation that explicitly call for social justice in the ideology of Pancasila, as if no longer ignore the ideals of the common good. One obvious example that I want to raise in this paper is a matter of government policy on mining Production Operation IUP instead of bringing prosperity, but instead brings misery and disaster for the community. Facts on the ground prove that mining is actually threatening the welfare of the community and environmental sustainability. In this study I want to examine the Government's policy on business licenses, mining production mining operations in achieving a sense of justice for communities around the mines.

Government policy is my analysis from the perspective of government policy that gave birth to social justice. With the data and resources available, I tried to formulate, the extent to which government policy on mining permit mining production operations for people to improve their welfare, it could have been with the government policy on mining businesses fail to realize the ideals of social justice. At the same that any policy issued should see and examine the quality of the environment surrounding the mine. Due to the declining quality of the environment coupled with the depletion of natural resource stocks and the emergence of a variety of environmental problems humans have been aware of the importance of the support of the environment and the role of natural resources for human life in the universe. Environment cannot support the amount of human life and of living things are without limit. If this earth is no longer able to support the explosion of human beings and their activities, then humans will experience a variety of difficulties. Absolute growth of the population of the earth shall be controlled and human activity must be environmentally sustainable [1].

Preservation of the environment means that the environment should be maintained as the situation. Therefore the environment must be utilized within the framework of development and to the welfare of society. This condition means that the environment is undergoing a process of change. The change process needs to be maintained in order to keep the environment is able to support a normal life [2], according to the carrying capacity and environmental capacity. Licensing, often times be a problem in everyday life. Ranging from ordinary citizens to officials, struggling with permissions, because the permissions associated with the 
interests of the people wanted to do certain activities with the approval or the legality of government officials as a tool in the government administration in particular. As a policy would permit shall not be inconsistent with the laws and regulations and norms that exist in society both vertically and horizontally.

The policy should reflect the shape of a permit in accordance with the policies pry live and comfort throughout the community, so that the purpose of the concept of the welfare state which written in the Preamble of the Constitution of the Republic of Indonesia 1945 fourth paragraph can be realized. In 1945 the opening to realize government yang concentration on the welfare of society and it has been mandated that: (1) The Government shall provide protection to the whole Indonesian nation and the entire territory of Indonesia; (2) Government is obliged to promote the general welfare; (3) Government is obliged to educating the nation. The concept of government for the welfare law is closely related to the role of government administration. Welfare state refers to the active role of the government to manage and organize economy. The four main pillars of the welfare state [3]: The first, social citizenship, second, a full democracy, third, Modern industrial relations system, and the fourth is Right to education and the expansion of modern education system manses. Every social welfare state is the right of citizens to be offset by economic growth and employment.

Indonesia is one of the Governments in the world that has a lot of natural resources [4]. Natural resources exist that can be updated (renewable), and there are also non-renewable (undeniable). Natural resources are not renewable, such as oil and gas, gold, copper, silver, coal, and others. Natural resources, in the form of oil and gas, gold, copper, silver, coal and the other controlled by the Government and used for the prosperity of the people. In Article 33 paragraph (3) of the 1945 Constitution stated: "The earth and water and the natural riches contained therein shall be controlled by the State and used for the prosperity of the people".

State mastery over natural resources, especially minerals or mines described back in the legal considerations Act No. 4 of 2009 on Mineral and Coal Mining (Government Gazette of the Republic of Indonesia Year 2009 No. 4, Supplement to the Government of the Republic of Indonesia Number 4959). In the consideration of the law, stated that: "Mineral and coal contained within the Indonesian mining law is a nonrenewable natural resources as the gift of God Almighty which has an important role in meeting the livelihood of many people, because it managed to be controlled by the State to significantly add value to the national economy in order to achieve prosperity and welfare equitably ". There are three essential elements listed in the mining law Act 4 of 2009, which includes: (1) The existence of mineral resources and coal; (2) Mastery of the Government; and State mastery goal. The government is based on Pancasila and the Constitution of the Republic of Indonesia Year 1945, all aspects of life in the areas of society, including the government must always base on the law. Indonesia is a country of law, the law of the State according [5], the government officials and community members organized and subject to the law. In addition to the charge of the strategic materials, the function and role of government as a regulator and entrepreneur as the state-run mining by Law No. 4 of 2009, function and role of government in the mining turned into solely as a regulator.

Efforts to create jobs and social justice for communities around the mining area as a form of public welfare, then every entrepreneur who is given the right to manage the goods existing mines in the bowels of the earth, in conducting its business activities in the field and related to natural resources required to carry out social and environmental responsibility. Thus, this issue is very interesting and deserves to be questioned, and then studied and analyzed in depth through this research proposal titled "Government Policy on Production Operation IUP Mining towards social justice for Surrounding Communities".

\subsection{Relationship Between Mining Law and the Law of Agrarian \\ II. Literature Review}

Mineral and coal mining law has a very close relationship with the Agrarian law. It is closely related to the use of land for mineral and coal mining activities. For those individuals or businesses who will perform mineral and coal mining activities, then that should be caught early is the legal status of the land to be used, whether the status of land ownership rights, lease rights, land rights, rights of use, and or Government land. Each preparation of legislation should be based on the foundation of philosophical, juridical and sociological. Philosophical grounding means as outlook or mental attitude of society towards the implementation of mineral and coal mining. Inner attitude or outlook of Indonesia on the implementation of mineral and coal mining activities, affirmed in the Preamble of the 1945 Constitution, and the Law No. 4 of 2009 on Mineral and Coal.

With the license, they can conduct mining activities well. With the mining activities, it is expected to be a prosperous society, both economically and socially community. Yet in realistic, the activities carried out by local residents received less attention from the government, especially local government because many people who do illegal mining activities (illegal mining) they are left alone without guidance and supervision. As a result, the locals were doing illegal mining many died buried by landslides. Even the illegal mining in the implementation of the applicable law of the jungle, meaning that whoever is strong, and then he who controls 
mining wells that had been dug by others. If it is allowed, it will cause problems and substantial losses, both for the community and local government.

\subsection{Understanding Mining Permit}

Basically, mining activities are carried out by people or society or a legal entity or business entity, can be classified into two types, namely: (1) Illegal mining is an activity undertaken by a person or community without Permission from the competent authority and (2) Legal mining is the mining activities undertaken by the business entity or legal entity based on a license issued by the competent authority. One form of the permit, the mining business license (IUP). The term mining license derived from the English translation, namely the mining permit. Mining business license (IUP) is a "Permit to carry out mining" [6]. If we analyze this definition, there are two most important elements in IUP, namely: first, the existence of a permit, and second, the mining business. Permit or approval is a statement that allows the holder to conduct mining business. Mining business or mining business is: "The activities in the framework of exploitation of mineral and coal which includes the stages of general investigation, exploration, a wealth of studies (feasibility study), construction, mining, processing and refining, transportation and sales, as well as post-mining activities" [7].

There are eight stages of mineral and coal exploitation activities. The eighth stage, including: general investigation, exploration, feasibility study, construction, mining, processing and refining, transportation and sales, and post mine. Based on the general provisions of the law No. 4 of 2009 on mineral and coal have defined that there are eight stages of mineral exploitation activities. Public inquiry is to determine the stage of mining activities: first, the regional geological condition, the second, is an indication of mineralization. An exploration stage mining operations to obtain detailed and accurate information about: location, mineral, mineral forms, dimensions minerals, mineral distribution, quality and resources of the excavated materials and environment measurable social and environmental. The feasibility study is the phases of mining operations to obtain information in detail all aspects related to determining, economical feasibility, technical feasibility of mining operations, environmental impact assessment and planning post mining.

Production operations are the stages of mining operations, which include: first, construction, secondly, mining, third, processing, fourth, purification, fifth, transportation and sales, and the sixth is a means of controlling environmental impacts in accordance with the results of the feasibility study. Construction is to conduct mining operations: first, to produce minerals, second, is an associated mineral. Processing and refining is to improve the mining business activities: first, the quality of the mineral and the second is to utilize and gain associated minerals. Freight is a mining business activity to: first, remove minerals from the mine; the second is the processing and refining to the place of delivery. The sale is to sell the mining activities of mining results.

IUP is a license granted to permit holders to carry two mining operations, both the mining activities, including, first, mineral mining, coal mining, and the second is. Mining is a mineral mining mineral assemblage in the form of ore or rock, outside the geothermal, oil and gas, as well as ground water. Coal mining is the mining of carbon deposits contained in the earth, including shale, peat, and rock asphalt. Furthermore, given the type of IUP to perform two activities is Exploration and Production Operation IUP [8]. IUP Exploration is a business license granted to undertake activities, which include, general investigation, exploration study eligibility. Production Operation IUP is a business license granted after the completion of an IUP Exploration to undertake production operations. Production Operation IUP License for activities including: construction, mining, processing and refining as well as transportation and sale. Who can apply for a Mineral and Coal IUP, namely: business entities, cooperatives and personality [9]? Enterprise is any legal entity which is engaged in mining established under Indonesian law and domiciled in the territory of the Government of the Republic of Indonesia [10]. Characteristic of a business entity may apply for IUP, namely: first, the legal entity which is engaged in mining, both, established under Indonesian law, and the third is the position of a business entity, namely the Government of the territory of the Unitary Republic of Indonesia.

Business entity can be divided into three kinds, namely: national private entities (BUMD), BUMN, and local government. [11] Characteristics of National Private Enterprises, namely: a legal entity, which is not a legal entity and or all of its shares (100\%) owned by participants in the country. Government Owned Enterprises (BUMN) is: "The business entity that all or most of the capital is owned by the Government through direct investments from the Government of wealth separated" [12]. Characteristics of BUMN (State-Owned Enterprises) who may apply for IUP Mineral and Coal, which is engaged in mining, both mineral and coal. For example, PT. Aneka Tambang.

\subsection{The Concept of Justice According to Law}

The word "fair" is drawn from the Arabic. Arabic Dictionary informs that this word originally meant "the same". The equation is often associated with things that are immaterial. In Big Indonesian Dictionary, the word "fair" [13] is defined as follows: 1) is not biased/non-partisan; (2) side with the truth; (3) fitting/not arbitrary. Justice is rooted word which means not just biased or balanced [14], it can also mean to side with the 
right or hold on to the truth and not act arbitrarily. The word is an adjective justice for all deeds and fair treatment. The man who first defines justice is Ulpian's a Roman jurist with the phrase "juice tribute Sum clique" which means giving each one based on rights.

While the meaning of the word fair Aristotle [15] divided into two senses, namely: Fair can mean a legally, and can also mean something comparable or appropriate. So that in his view, justice divided into two types: (1) a general virtue of justice as the spawned the concept of natural justice (justified universalize) the observance and compliance with the law; (2) a special virtue of justice as the spawned two concepts of justice, namely: (a) cumulative equity, and (b) distributive justice. Justice is marked as a special virtue of its properties which include the presence of a good relationship (harmony) between individuals, so that the pursuit of profit is based on a balance between the individual in question.

Thomas Aquinas distinguishes the sense of justice of three types: (1) commutative justice, (2) distributive justice, and (3) legal justice. Interpreted commutative justice as fairness with regard to the interests of the individual in the form of a balanced transactional inter individual. These types of justice, determination of inter individual rights based on the principle of balance. Distributive justice as fairness is related to the public interest to the public authorities in the community or the government in the context of regulating and distributing resources equitably to all citizens. Last are interpreted legal justice as obedience and adherence to the law and justice. Justice Thomas Aquinas third kind (legal justice) is to convey the same general justice according to Aristotle.

\subsection{Principles of Justice in the Law}

The use of the term principle [16] in the Big Indonesian Dictionary described the meaning of the principle and principle. Defined as the basic principle, while the principle is defined as the principle or truth as the basis of thinking and acting principal, principle also has a meaning as a basis. Thus, the use of the principle and the principle is accompanied having the same meaning in the context of both serve as basic guidelines to think and act. The principles of law used in the same sense as the basic legal principles and laws, though in principle there is a principle that is more principle than the principle itself [17]. Thus, the principle has a certain hierarchy. Ronald Dworkin argues that in law, the principle is a moral judgment about what is right and what is bad which includes the principles of political morality and political organization which justifies the method of interpretation under the law, and the principles of human rights to justify the substantive content of the decision court. This view can shape our understanding that the principles or the principles of social justice are the principles or the fundamentals of the most fundamental of which can be used as guidelines in social justice, both in the context of a particular community or government context. Such principles can be extracted from various sources for the Indonesian context), among other Western socialism, socialism teachings of Islam, and indigenous Indonesian collectivity (which is reflected in the Pancasila and the constitution of the government), then derived rules into law that will serve as the rules of law.

Related to the exploitation and utilization of natural resources in an efficient mining will impact directly or indirectly to the improvement of people's welfare as a whole [18]. Directly such as by building a power plant so that every household gets a source of energy and lighting by itself improve the quality of life of each family. Moreover, ruler of the mining sector is concerned with the environment also have direct impacts on the improvement of the structure of the life of the surrounding community. Then the mining sectors are indirectly impact on the overall improvement of people's welfare is government revenue in the form of taxes and norm-tax (royalties, fixed fees, dividends, and other levies. Revenue Government will not directly impact on improving people's welfare as a whole if Government revenue is used to efficiently build a public facility. Finally, related to the availability and needs of the people to mine materials and energy. Excavated materials and energy, although it's availability in large quantities but only consumed by a small number of people, then the excavated materials and energy production that does not include a branch that controls the lives of many people. Conversely, if the mining and energy availability but be needs a little crowd, the mining and energy production are classified as category branch that controls the lives of many people.

\section{Methods}

To reach research objective, it collected primary data with qualitative methods. In-depth interviews are done to informants to test validity of triangulation. This study was done in Southeast Sulawesi. Key informants are mining business leaders at PT. Ifishdeco Konawe southeast. The complement informants are head of mining agencies or friends of informants. This is done in order to test triangulation validity of data sources. In addition, it also used study Focus Group Discussion (FGD) with peers and experts in qualitative research related to mining license.

This approach is a research method that refers to research procedures to produce qualitative data in the form of expressions, records, and their behavior observed. Therefore, researchers will focus on experience and life practice of mining license. In connection with issue and focus and purpose of research, then the other does 
not become main instrument, unless the executor or the researchers themselves. Other supporting instruments used are notebook, tape recorder as recording equipment, cameras and mobile phones. This research was conducted at PT. Ifishdeco Konawe southeast. South Sulawesi is the main reason researchers in conducting research in the field of government policy on IUP production of coal mining and minerals as a means of empowering communities around the mines in order to create a sense of fairness in the presence of mines in the area. This research is qualitative research. To support the research, the data used in this study is a secondary data is data related facilities on Government policy permits mining production according Supporting elements of the mining management. To complement the secondary data, literature approach used also by taking the general theories of literature and previous similar studies, so that research results can be supported by accurate data.

Qualitative research data collection methods (human or researcher) are primary instrument. Data collection method in this study is: (1) observations, this technique is done to find objective phenomenal data where informant was not known by observed object. This technique is done in some places or situations, either planned or unplanned, but always according with needs of data relevant to research objectives, (2) interviews the informant conducted freely and deeply, and not scalable. Those interviewed were selected mining business leaders at PT. Ifishdeco Konawe southeast and head of mining agencies with research objectives and (3) study documentation that carried out by taking photos of activities respondents. In addition, the documentation also conducted to collect notes, and text that related to research. Methods of data collection in this study is done by using two (2) approaches, namely: (1) The research literature relating to the subject matter to be investigated; (2) The field research conducted with the direct object of the research is the Government Policy On Production Mining Permits In efforts to create a sense of justice for the surrounding community.

Data collection in this study will be carried out in 3 stages: First, data is collected by observing and interviewing several people (key figures) from mining entrepreneur and key figures who knew a lot about mining license. Second, in-depth interviews are done to respondents who considered a source that has a lot more knowledge and deep understanding of various information required. This stage also is made further observations, by collecting various relevant texts. Finally, focus group discussions conducted to confirm deeply observations, interviews, and interpretation of information that has been achieved, before final conclusion made. Data/information collection strategies are used to facilitate data collection or accurate information acquisition. The Steps used is follows: First, informant goes at place and at most fun time (at leisure). Second, to know rightly informants address. Third, to visit each respondent home and office many times if information is still required as part of triangulation.

Implementation of Government Policy On Production Mining Permits In efforts to create a sense of justice for the surrounding community, using equipment Participatory Rural Appraisal (PRA) is modified according to the needs of the field, where, according [19] states that PRA methods useful for many purposes and methods for: (1) collect data and information, (2) analyzing information, (3) collecting and analyzing the data with PRA tools; and (4) communication or confirmation. To realize the four objectives of the PRA, the technique performed the following methods:

1. Digging / reviewing secondary sources

2. Direct observation on the object

3. Determine key indicators

4. A semi-structured interview

5. Rankings and scores

6. Creating and analyzing Maps and Models, transects and diagrams

7. Conducting case studies in specific regions

8. Workshops / seminars

9. Triangulation of data

10. Reporting and analysis of policy implications and sustainability.

\section{Results and Discussion}

Based research objective, qualitative method with depth interviews with informant has achieved the following results. This research was conducted at PT. Ifishdeco Konawe South and in this study also showed that, earth, water and natural resources contained in the surface and deep within the earth is God's grace to be thankful for the people of Indonesia. According to one of the employees of PT. Ifishdeco, [21] that: "all mining companies are based on Law No. 4 of 2009 on Mineral and Coal management, functions and role of government in the mining turned into solely as a regulator". To the opinion of the researchers that the Government Policy on Production Operation IUP mining on the direction of national development as referred to in Article 3 , formulated explicitly that "justice and prosperity must be reflected in all aspects of life. All people have equal opportunities in improving the standard of living, to obtain employment, social services, education and health, freedom of expression, political rights implementing, securing and maintaining the Government; and get protection and equality of any kind, either between individuals, gender, and region". 
Results of interviews with [20] that: "companies also continue to promote responsibility towards the surrounding community, both aspects of the rule of law to get mining jobs for the surrounding communities as well as other aspects of well-being, therefore, through the means of power and authority existing or her Government in this case the company is obliged to organize, lead, directing his people or communities around the mines to achieve our goals/national". Management and control of the land, water sources and other natural resources, or better known as natural resources. Where the Government is responsible to lead and manage it properly and directed. Directional intent is to lead the Government in order to manage and use. Implementation of the management and utilization of natural resources is guided by the principles of sustainability and justice in the society. For the sake of a common goal are the welfare of the people and not the welfare of the few.

This study, when we do an interview about how companies are addressing the issue of land ownership policies against companies for mining, environmental management, mining permits with [21], PT. Ifishdeco, father [21] argues that: "The government formed Agrarian Act provisions aimed for the greatest prosperity of the national agrarian people. policy marked by the birth of the Basic Agrarian Law No. 5 of 1960 in the Act also put basics Political Mastery source natural resources/agrarian by the Government as the realization of Article 33 paragraph (3) of the 1945 Constitution In employment, to adapt to the needs of the rearrangement of the agrarian law by incorporating the principles of the protection of the rights of the people, then passed through the provision of the People's Consultative Assembly (MPR) No. IX of 2001 on agrarian reform and natural resources management. Both regulations later became the principal guideline of Agrarian policy, which is national ".

According to the researchers, that: "if we look carefully at the BAL is essentially agrarian settings, each of which is general, not sectored because when we trace more specifically, it is an agrarian sense whole earth's surface, water and natural resources contained above Earth's surface, including within the bowels of the earth, which according to the concept of earth science/geology better known by the term of Natural Resources (SDA). It other important then becoming BAL shrimp Agrarian law because in one of the provisions have been expressly laid mastery of political forms national agrarian, this provision could we see in article 2 paragraph (1). "On the basis of the provisions of Article 33 paragraph (3) of the Constitution, and the matters referred to in Article 1 stated that earth, water and natural resources therein shall be controlled by the Government, as the supreme organization of an entire region and its people", hereinafter in paragraph (3) in the same chapter" authority that originates in the master rights of the Government in paragraph (2), this section is used to reach for big prosperity ". In line with the sound of the second paragraph in these articles are not directly have also corroborated that the BAL as a form of agrarian policy of the Government in the field, as well as a form of political control of the national agrarian".

Government policy on environmental pollution, the results of this study indicate that the government's policy towards environmental pollution implemented through environmental management including prevention, mitigation of damage and pollution. Improvement of the quality of the environment has demanded the development of a variety of policy tools and programs and activities supported by a support system of environmental management. The system includes institutional stability, human resources and environmental partnerships, in addition to the laws and regulations, and funding information. Linkages and overall environmental aspects has given the consequences that environmental management, including its supporting system cannot stand alone, but integrated with the rest of the construction work. National development has been carried out has a goal to improve the welfare of society. The purpose is to make development has several disadvantages, which are very prominent include the observance of rules is not matched by development actors or often ignore the rules of proper grounding in managing the business and or activities that they do, especially regarding the social and environmental fields, giving rise to environmental problems in the region or in the location of the mining regions such as in the mining location PT. Ifishdeco South Konawe.

Follow the plan in accordance with the Protection and Sustainable Development in Environmental Management is done to improve the quality of the environment through the development and enforcement efforts of the legal system as well as environmental remediation efforts. Furthermore attitude of Mines Creating Entrepreneurs Benefit to Society, The concern in this study is the efforts of employers and the Government in relation to the existence of communities around the mines. Employers and government relations in the mining area to see the potential of mining management, always avoid, natural resource conflicts, identity conflicts, with the surrounding community mining. Conflicts arising from government policies caused the disparity of resources (materials, power, political access, and authority) as stated [24], a conflict occurs because the parties to the conflict have different objectives. Conflicts can also occur because the purpose of the parties involved in the same conflict, but the way to achieve it is different.

Apart from the conflict of policies also occur from policy-making and implementation process. "There is some possibility that the cause of a policy or decision rejected the implementation process, first, the target group does not require nor benefit from policies or decisions. You can guess that the decision is rejected once formulated in a conversion process that elitist. The second possibility of rejection or policy decisions by the 
target group as the target audience is not aware of the benefits of the decision, and therefore they do not feel the need said [22], a community around PT. Ifishdeco.

This study also examines the emergence of policy on minerals and coal mines that make communities feel in exile. Many impact caused by the issuance of this policy, especially for the miners in the Southeast. According [23] that: "business class mines A and B are the affairs of the central government, local government affairs only class $\mathrm{c}$, so it is ironic when it is said that the local government should be responsible for empowering communities around the mines to be employees of the company, or develop facilities roads or whatever his name because such matters are matters for the mining companies and the central government, local governments and communities in order to facilitate the company going good communication between communities and employers. Local governments will remain a mediator in accommodating the public interest in the company ". The results of this research note that there is resistance on the part of the association and the community to review the contents of the law so as not adverse local community. Explanation has previously been explained what the cause and trigger of the community resistance issuance of Law No. 4 of 2009 and throughout the issuance of this policy to date has not been enforced because of the contents of the Act. There was resistance by the community on the policy issued by the Central Government to give the sense that the original policy was made by the central government so that presents a conflict with other words such policies are insensitive to the conflict. Moreover, it can be said as well as the policy generates conflict because not invited stakeholders.

\section{Research Implications}

Enforcement is a measuring tool for the creation of a good legal system and implemented on an ongoing basis, among other things, that: (1) administrative law enforcement in the environmental field can be optimized as a prevention device; (2) Law enforcement administration (preventive) may be more efficient from the point of financing compared to civil and criminal law enforcement. Financing to cover the cost of administrative law enforcement surveillance conducted field and laboratory tests routinely cheaper than the effort of collecting evidence, field investigations, hiring expert witnesses to prove aspects of causality (cause and effect) in criminal and civil cases; (4) administrative law enforcement has the ability to invite more community participation. Community participation is done starting from the licensing process, monitoring of compliance/supervision, and participation in the filed objections and requested state administrative officials to impose administrative sanctions.

\section{Conclusions and Recommendations}

Government Policy on Production Operation IUP Mining to environmental management, including prevention, mitigation of damage and pollution and restoration of environmental quality has demanded the development of a variety of policy tools and programs and activities supported by other environmental management support system. Government as formal institutions that regulate governance government inventories, regional policy making in addressing environmental issues, especially issues of policy and enforcement where mining license for the mining production operations can improve the welfare of society, it could have been with the government policy on mining business. The role of government, in addition to making and setting policy and monitoring related to environmental management and sustainable natural resources to maintain the balance of supply capacity of Natural Resources in the future, should also be campaigning and supporting actor, in this case providing funds for institutions or individuals who renew technology environmentally friendly. The policy should reflect the shape of a permit in accordance with the policies pry life and comfort throughout the community, so that the purpose of the Government in the concept of government welfare which written in the Preamble of the Constitution of the Republic of Indonesia 1945 paragraph four, can be realized.

Management of mining required a container or institution, the management of mineral and coal from both private and government-owned enterprises. For that, the nature of the existing mining companies should basically be done by the Government or the Government Company/region, while domestic private companies/foreign can only act as a contractor from Government and corporate entities owned Enterprises (BUMN). So the mining companies have not been able to also write principally for the benefit of communities around mining both the means school buildings, health buildings (hospitals) or adequate roads for the benefit of the surrounding community. The policies that have been set by the government is quite appropriate in terms of maintaining a sustainable balance of natural resources, but should the government's role not only as a policy maker (legislative) and the controller alone, but there are some things that should be done by the government, among others, creating prosperity and justice the presence Mining Company. In this case, oblige the company to establish a community around the school building for mining, building health and infrastructure development in trying to do so around the mining community can use it; do not have to eke $\mathrm{k}$ when other school districts, to be healthy, and to find a job, therefore serve the community as employees of the company. 
Socialize with the right policies government to entire community, in order to increase public awareness to participate to maintain and improve environmental quality. And actively participate in the company mining. Institutional capacity building and human resource (HR) such as knowledge and skills in the management of human resources and developing a Corporate Social Responsibility (CSR).

\section{References}

[1] Pramudya Sunu, 2001, Melindungi Lingkungan dengan Menerapkan ISO 14001, PT Gramedia Widiasarana Indonesia, Jakarta.

[2] Widia Edorita, 2007. Peranan Amdal Dalam Penegakan Hukum Lingkungan Di Indonesia Dan Perbandingannya dengan Beberapa Pemerintah Asia Tenggara, Universitas Andalas.

[3] Rafael Rela, 2002. Opini, www, kompas. com, Kebijakan Pertambangan dan Problem Keadilan Sosial, diakses 22 Juni 2013.

[4] Nyoman Nurjaya, "Indonesian Environmental Law Development And Reform: From Dutch Ordormantie, The 1982 Basic Environment Management Act to the Human Environment Management Act Of 1997", paper presented at the International Seminar on Environmental Law Development and Reform of Asian Countries, Canada, and Australia: A Comparative Perspective, jointly organized by Faculty of Law Brawijaya University and Faculty of Law Trisakti University on 25 to 27 February, 2008 at Klub Bunga Butik Resort, Batu, Malang, East Java, hlm. 1

[5] Achmad Ruslan, 2009, "Legal Drafting" Prosedur dan Pembentukan Peraturan Perundang-Undangan (Perda), diselenggarakan oleh Pemerintah Provinsi Sulawesi Selatan di Makassar, tanggal 24 - 25 Maret 2009.

[6] Undang-Undang Nomor 4 Tahun 2009 tentang Pertambangan Mineral dan Batubara. Pasal 1 angka 7

[7] Undang-undang Nomor 4 Tahun 2009 tentang Pertambangan Mineral dan Batubara Pasal 1 angka 6

[8] Undang-Undang Nomor 4 Tahun 2009 tentang Pertambangan Mineral dan Batubara, Pasal 36

[9] Undang-Undang Nomor 4 Tahun 2009 tentang Pertambangan Mineral dan Batubara, Pasal 38

[10] Undang-undang Nomor 4 Tahun 2009 tentang Pertambangan dan Batubara, Pasal 1 angka 32

[11] Penjelasan Pasal 38 Undang-Undang Nomor 4 Tahun 2009 tentang Pertambangan Mineral dan Batubara

[12] Pasal 1 angka UU Nomor 19 Tahun 2003 tentang Badan Usaha Milik Pemerintah

[13] M. Quraih Shihab, Wawasan Al-quran, Tafsir Tematik atas pelbagai Persoalan Ummat, Mizan, Bandung, 2007, hlm, 148.

[14] Muh. Suarif, Prinsip Keadilan dalam Penyelesaian Perselisihan Hubungan Industri di Indonesi, Disertasi PPS Unair, Surabaya, 2002, hlm, 10 .

[15] Muijber 1982, Filsafat Hukum dalam Lintasan Sejarah, Yayasan Kanisius, Jogyakarta, 1982, hlm, 29.

[16] M. Arifin Hamid, 2007, Membumikan Ekonomormi Syari’ah di Indonesia, Perspektif Sosio-yuridis, Elsas, Jakarta, 2007, hlm, 111.

[17] Otje Salman, Teori Hukum, Mengingat, Mengumpulkan dan Membuka Kembali, Refika Aditama, Bandung, 2004, hlm, 93-94.

[18] Abrar Saleng, Hukum Pertambangan, UII Press, Jogyakarta, 2004, hlm, 36.

[19] Rianse Usman; Metodologi Penelitian Sosial dan Ekonomormi, Penerbit Alfa Beta Bandung, 2009., h., 145

[20] Haryanto Wawancara, tanggal 4 Juli 2013 di kantor PT. Ifishdeco Konawe Selatan

[21] Arya Darmawan Wawancara, tanggal 4 Juli 2013 di kantor PT. Ifishdeco Konawe Selatan

[22] Samsuddin Wawancara, tanggal 23 September 2013

[23] Kadis Pertambangan Kabupaten Konawe Selatan Wawancara, tanggal 12 agustus 2013

[24] John Rawls, 2006, A Theory of Justice (Teori Keadilan, Dsar-dasar Filsafat Politik Mewujudkan Kesejahteraan Sosial Pemerintah), Pustaka Sinar Harapan, Jakarta.

[25] Internet, www. Crayon.org/mw/.,Norma-Norrma yang Berlaku dalam Kehidupan Bermasyarakat dan Berbangsa dan Bernegara, diakses, 22 Juni 2013. 